\title{
Nutrition substance of Thunnus sp. as an alternative to improving community nutrition
}

\author{
Andi Syamsiah Adha ${ }^{1}$, Suriyanti ${ }^{2}$, Fatmawaty Mallapiang ${ }^{3}$ \\ ${ }^{1,2}$ Bagian Gizi Universitas Islam Negeri Alauddin \\ ${ }^{3}$ Bagian Kesehatan dan Keselamatan Kerja Universitas Islam Negeri Alauddin
}

\begin{abstract}
Thunnus sp. (Tuna fish) is a group of fish which is the main export commodity of sea fish consumed from Indonesia. Tuna is one type of sea fish that has high protein levels. This study aims to determine the nutrient content (water content, ash content, carbohydrate, protein, fat, and iron (Fe), bacterial and mold microorganism test, organoleptic test, and $P<0.05$ friedmen test on tuna meat flour. The design in this study was experimental with a pre-experimental One-Shot Case Study design with the treatment of tuna meat flour drying. The results of the study with replication three times showed that the average water content was $8.37 \%$, ash content was $3.86 \%$, $3.99 \%$ carbohydrates, $71.45 \%$ protein, $9.45 \%$ fat, and $1.49 \mu \mathrm{g} / \mathrm{g}$ Fe. Microorganism test on bacteria for all 3 treatments was all safe. In addition there was an influence on the quality of tuna meat flour from aspects of color, aroma, texture. Therefore drying tuna meat flour at a temperature of $60^{\circ} \mathrm{C}$ is the best product that is fit for consumption as an additional food to meet the nutritional needs of the community every day.
\end{abstract}

Keyword: tuna fish; thunnus sp; nutrition substance; flour

\begin{abstract}
ABSTRAK
Ikan tuna (Thunnus sp) merupakan sekelompok ikan yang menjadi komoditas utama ekspor ikan laut yang dikonsumsi asal Indonesia. Tuna merupakan salah satu jenis ikan laut yang memiliki tingkat protein yang tinggi. Penelitian ini bertujuan untuk mengetahui kandungan zat gizi (kadar air, kadar abu, karbohidrat, protein, lemak, dan besi (Fe), uji mikroorganisme bakteri dan kapang, uji organoleptik, dan uji friedmen $\mathrm{P}<0,05$ pada tepung daging ikan tuna. Rancangan pada penelitian ini adalah eksperimentatif dengan desain pra- eksperimen One-Shot Case Study dengan perlakuan pengeringan tepung daging ikan tuna. Hasil penelitian dengan replikasi sebanyak 3 kali menunjukkan bahwa rata-rata kadar air diperoleh 8,37\%, kadar abu 3,86\%, karbohidrat 3,99\%, protein 71,45\%, lemak 9,45\%, dan Fe 1,49 ug/g. Uji mikroorganisme pada bakteri untuk ke-3 perlakuan semua aman. Selain itu ada pengaruh kualitas tepung daging ikan tuna dari aspek warna, aroma, tekstur.. Oleh karena itu pengeringan tepung daging ikan tuna pada suhu $60^{\circ} \mathrm{C}$ merupakan produk terbaik yang layak konsumsi sebagai makanan tambahan guna memenuhi kebutuhan zat gizi masyarakat setiap hari.
\end{abstract}

Kata kunci: ikan tuna; thunnus sp; kandungan gizi; tepung

\section{PENDAHULUAN}

Ikan adalah sumber makanan dari hewan yang sangat bermanfaat, baik dari segi kuliatas maupun kuantitas. Sekitar 60\% dari asupan protein hewani dalam $18,1 \mathrm{~kg}$ dikonsumsi per orang per tahun, frekuensi konsumsinya, jauh melebihi dari sumber makanan hewani lainnya (Belton \& Thilsted, 2014).

Produksi perikanan Indonesia hingga triwulan III tahun 2015 mencapai 14,79 juta ton. Untuk komoditas perikanan tangkap ikan tuna mengalami pertumbuhan produksi dari triwulan I hingga triwulan III 
tahun 2015 sebesar 27,22\% dengan rata-rata produksi sebesar 79 ribu ton. Pertumbuhan yang paling signifikan untuk komodidas ikan tuna adalah tuna albakor, tuna sirip biru dan tuna mata besar) produksi perikanan laut yang dijual di Tempat Pelelangan Ikan (TPI) di Sulawasi Selatan pada tahun 2014 sebesar $4.730 \quad \mathrm{kw} / \mathrm{Q}$. (Rahmantya et al., 2015)

Ikan tuna adalah jenis ikan dengan kandungan protein yang tinggi dan lemak yang rendah. Ikan tuna mengandung protein antara 22,6 - 26,2 g/100 g daging, lemak antara $0,2-2,7 \mathrm{~g} / 100 \mathrm{~g}$ daging. Ikan tuna mengandung mineral ( kalsium, fosfor, besi, sodium), vitamin A ( retinol), dan vitamin B (thiamin, riboflavin, dan niasin) (Hadinoto \& Idrus, 2018)

Untuk meningkatkan pemanfaatan dan nilai tambah ikan tuna dapat diolah menjadi tepung ikan. Pemanfaatan ikan tuna dalam produk pangan sebagai tepung ikan belum dilakukan secara maksimal. Tepung ikan merupakan sumber protein yang sangat baik karena dapat meningkatkan konsumsi makanan. (Fatmawati \& Mardiana, 2014)

Tepung ikan merupakan salah satu produk pengolahan hasil ikan. Pembuatan tepung ikan berbahan dasar ikan tuna dapat menjadi alternatif bahan pangan. Selain memiliki daya simpan yang cukup lama dibandingkan dengan ikan segar, bentuk tepung ikan lebih fleksibel dalam pemanfaa- tannya.

Penelitian ini bertujuan untuk mengetahui kandungan zat gizi (kadar air, kadar abu, karbohidrat, protein, lemak, dan besi (Fe), uji mikroorganisme bakteri dan kapang dan uji organoleptik

\section{METODE PENELITIAN}

Pendekatan penelitian yang digunakan dalam penelitian ini adalah pendekatan eksperimentatif dengan menggunakan desain pra-eksperimen, Model pra-eksperimen yang digunakan yaitu One-Shot Case Study. Dalam Model One- Shot Case Study terdapat sutu kelompok diberi perlakuan/treatment dan diobservasi hasilnya. Selain itu dilakukan uji laboratorium untuk mengetahui kadar total kandungan zat gizi (kadar air, kadar abu, karbohidrat, protein, lemak, dan Fe), dalam tepung daging ikan tuna dengan suhu pengeringan oven $40^{\circ} \mathrm{C}, 50^{\circ} \mathrm{C}$, dan $60^{\circ} \mathrm{C}$.

\section{HASIL PENELITIAN}

Parameter yang dianalisis adalah kadar air, kadar abu, kadar karbohidrat, kadar protein, kadar lemak, kadar zat besi , mikrobiologi dan organoleptik.

Berdasarkan tabel 1 menunjukkan bahwa kadar air tertinggi terdapat pada suhu $40^{\circ} \mathrm{C}$ yaitu $23,51 \%$ dan tepung daging ikan tuna pada suhu $50^{\circ} \mathrm{C}$ sebanyak $10,81 \%$ selanjutnya yang paling sedikit pada perla- 
kuan suhu $60^{\circ} \mathrm{C}$ sebanyak 8,37\%. Kadar abu tertinggi terdapat pada suhu $60^{\circ} \mathrm{C}$ yaitu $3,86 \%$ dan selanjutnya pada perlakuan suhu $50^{\circ} \mathrm{C}$ sebanyak $3,61 \%$ selanjutnya yang paling sedikit pada perlakuan suhu $40^{\circ} \mathrm{C}$ sebanyak $2,96 \%$.

Kadar karbohidrat tertinggi terdapat pada suhu $60^{\circ} \mathrm{C}$ yaitu $3,99 \%$ dan selanjutnya pada perlakuan suhu $50^{\circ} \mathrm{C}$ sebanyak $3,48 \%$ selanjutnya yang paling sedikit pada perlakuan suhu $40^{\circ} \mathrm{C}$ sebanyak 3,38\%. Kadar protein tertinggi terdapat pada suhu $60^{\circ} \mathrm{C}$ yaitu $71,45 \%$ dan selanjutnya pada perlakuan suhu $50^{\circ} \mathrm{C}$ sebanyak $67,76 \%$ selanjutnya yang paling sedikit pada perlakuan suhu $40^{\circ} \mathrm{C}$ sebanyak 57,57\%. kadar lemak tertinggi terdapat pada suhu $50^{\circ} \mathrm{C}$ yaitu $9,46 \%$ dan selanjutnya pada perlakuan suhu $60^{\circ} \mathrm{C}$ sebanyak $9,36 \%$ selanjutnya yang paling sedikit pada perlakuan suhu $40^{\circ} \mathrm{C}$ sebanyak 9,21\%. Kadar $\mathrm{Fe}$ (besi) tertinggi terdapat pada suhu $40^{\circ} \mathrm{C}$ yaitu $1,49 \mathrm{ug} / \mathrm{g}$ dan selanjutnya pada perlakuan suhu $60^{\circ} \mathrm{C}$ sebanyak $1,47 \mathrm{ug} / \mathrm{g}$ selanjutnya yang paling sedikit pada perlakuan suhu $50^{\circ} \mathrm{C}$ sebanyak $1,47 \mathrm{ug} / \mathrm{g}$.

Data tabel 2 menunjukkan bahwa pembuatan sampel tepung daging ikan tuna (Thunnus sp) pada tahap perlakuan suhu pengeringan dengan 3 kali percobaan maka diuji analisis kualitas tepung dengan total mikoorganisme sehingga data hasil yang terlampir. Penentuan kualitas tepung dapat diketahui jumlah koloni yang dikategorikan aman berada $<10.000$. Jadi suhu pengeringan tepung daging ikan tuna yang aman adalah suhu $60^{\circ} \mathrm{C}$ dengan total bakteri 2.176,6 koloni/gram dan total kapang sebanyak 4.666,6 koloni/gram.

Sedangkan suhu yang lain dikategorikan tidak aman karena melebihi amban batas, pada suhu $50^{\circ} \mathrm{C}$ total bakteri 12.750 koloni/gram dan kapang sebanyak 35.813,3 koloni/gram, dan pada suhu $40^{\circ} \mathrm{C}$ dengan total bakteri 14.986,6 dan kapang sebanyak 42.623,3 koloni/gram.

Berdasarkan tabel 3 dapat diketahui bahwa mutu hedonik yang baik dengan skor $>4$ dalam tepung daging ikan tuna (Thunnus sp) terdapat pada formula F2 $\left(50^{\circ} \mathrm{C}\right)$ yaitu 4,5 dengan kriteria warna biasa, pada aroma terdapat pada formula F3 $\left(60^{\circ} \mathrm{C}\right)$ yaitu 4,7 dengan kriteria biasa, dan pada tekstur terdapat pada formula F3 $\left(60^{\circ} \mathrm{C}\right)$ yaitu 5,8 dengan kriteria agak halus. Sedangkan uji over all mutu hedonik dalam tepung daging ikan tuna (Thunnus sp) dari 3 formula memiliki skor $>4$ dengan kriteria agak baik pada uji over all mutu hedonik paling tinggi pada formula $\mathrm{F} 3\left(50^{\circ} \mathrm{C}\right)$ dengan skor 5,4 .

Berdasarkan tabel 4 bahwa total skor tertinggi dalam tepung daging ikan tuna (Thunnus sp) terdapat pada formula F3 $\left(60^{\circ} \mathrm{C}\right)$ dengan total skor $304(68 \%)$ dengan kriteria suka, dan terendah pada formula F1 
$\left(40^{\circ} \mathrm{C}\right)$ dengan total skor $213(54 \%)$ dengan biasa.

\section{PEMBAHASAN}

Kadar air merupakan salah satu indikator penting dalam pengeringan buahbuahan, sayur-sayuran dan dagingdagingan. Tujuan utama pengeringan yakni menurunkan kadar air bahan pangan sampai batas tertentu sehingga mikroorganisme tidak dapat tumbuh lagi di dalamnya.

Tingginya kadar air pengeringan dalam oven suhu $40^{\circ} \mathrm{C}$ disebabkan karena dimungkinkan masuk kembali ke dalam sampel karena sampel berada dalam ruang tertutup.

Sedangkan pada tepung pengeringan dengan suhu $50^{\circ} \mathrm{C}$ dan $60^{\circ} \mathrm{C}$ memiliki kadar air lebih rendah disebabkan karena sampel berada pada suhu tinggi sehingga air yang menguap dari sampel dapat berkurang dengan baik. Kemampuan bahan untuk melepaskan air dari permukaannya akan semakin besar dengan meningkatnya suhu udara pengering yang digunakan dan makin lamanya proses pen-

Tabel 1. Hasil Pemeriksaan Uji Mikrooganisme Analisi Kualitas Sampel

\begin{tabular}{llll}
\hline & \multicolumn{3}{c}{ Suhu Pengering $(\%)$} \\
\cline { 2 - 4 } Kadar & $40^{\circ} \mathrm{C}$ & $50^{\circ} \mathrm{C}$ & $60^{\circ} \mathrm{C}$ \\
\hline Air & 23,51 & 10,81 & 8,37 \\
Abu & 2,96 & 3,62 & 3,86 \\
Karbohidrat & 3,38 & 3,48 & 3,99 \\
Protein & 57,57 & 67,76 & 71,45 \\
Lemak & 9,21 & 9,45 & 9,36 \\
Zat Besi (Fe) & 1,49 & 1,38 & 1,47 \\
\hline
\end{tabular}

Sumber: Data Primer, 2017

rendahnya suhu dalam pengovenan, sampel berada dalam kondisi tertutup dan air yang menguap dari sampel tetap ada di dalam oven sehingga adanya kemungkinan bahwa uap air tersebut dapat masuk kembali ke dalam sampel.

Hal ini sejalan dengan penelitian Haryanti \& Hidajati, (2013) dalam penelitiannya pengaruh metode pengeringan terhadap kualitas tepung cacing sutra menyatakan bahwa uap air pada pengeringan oven geringan, sehingga kadar air yang dihasilkan semakin rendah.

Kadar abu yang diperoleh pada pengeringan daging ikan tuna dengan berbagai perbedaan suhu kadar daging ikan segar pada penelitian yang dilakukan oleh (Putri, 2012) yaitu sebesar $1,2 \%$. Setelah proses pengeringan pada waktu 8 jam menujukkan nilai kadar abu pada suhu $40^{\circ} \mathrm{C}$ sebesar $2,9 \%$, selanjutnya pada suhu $50^{\circ} \mathrm{C}$ sebesar $3,62 \%$ dan suhu $60^{\circ} \mathrm{C}$ sebesar 
3,86\%. Hal ini menunjukkan bahwa kadar abu tertinggi pada suhu $60^{\circ} \mathrm{C}$, kenaikan nilai kadar abu ini terus berlangsung dengan semakin lamanya waktu yang digunakan selama proses pegeringan.

Peningkatan suhu pengeringan menyebabkan kenaikan kadar abu karena dengan meningkatnya suhu mengakibatkan kadar air semakin menurun sehingga semakin banyak residu yang ditinggalkan dalam bahan. Semakin tinggi suhu pengeringan oven akan meningkatkan kadar abu karena peningkatan suhu yang sesuai dalam tinggi suhu pengeringan akan meningkatkan kadar abu karena air yang keluar dari dalam bahan semakin besar.

Berdasarkan hasil analisis karbohidrat dari tiga metode pengeringan dalam pembuatan tepung daging ikan tuna (Thunnus sp), menunjukkan bahwa kadar karbohidrat tertinggi terdapat pada suhu $60^{\circ} \mathrm{C}$ yaitu $3,99 \%$ dan selanjutnya pada perlakuan suhu $50^{\circ} \mathrm{C}$ sebanyak $3,48 \%$ selanjutnya yang paling sedikit pada perlakuan suhu $40^{\circ} \mathrm{C}$ sebanyak $3,38 \%$.

Kenaikan nilai kadar karbohidrat ini

Tabel 2. Hasil Pemeriksaan Uji Kadar Zat Gizi dalam 100g Tepung Daging Ikan Tuna

\begin{tabular}{llll}
\hline & \multicolumn{2}{c}{ Jumlah Koloni /gram } \\
\cline { 2 - 4 } Mirkoba & $40^{\circ} \mathrm{C}$ & $50^{\circ} \mathrm{C}$ & $60^{\circ} \mathrm{C}$ \\
\hline Bakteri & $14.986,6$ & 12.750 & $2.176,6$ \\
Kapang & $42.623,3$ & $35.813,3$ & $4.666,6$ \\
\hline
\end{tabular}

Sumber: Data Primer, 2017

suatu proses pengeringan tidak mengakibatkan perusakan zat gizi bahan makanan terutama mineral, hanya mengurangi kadar air bahan makanan saja. Peningkatan kadar abu karena suhu dan waktu yang digunakan juga semakin meningkat yang berbanding terbalik dengan kadar air yang semakin menurun.

Menurut Sudarmadji (2007) kadar abu tergantung pada jenis bahan, cara pengabuan, waktu dan suhu yang digunakan saat pengeringan. Jika bahan yang diolah melalui proses pengeringan, maka semakin terus berlangsung dengan semakin meningkatnya suhu yang digunakan selama proses pegeringan sehingga menyebabkan kandungan air dalam bahan menurun dan tingginya konsentrasi karbohidrat yang terkandung didalam tepung. Kadar karbohidrat meningkat dipengaruhi oleh polisakarida, jenis polisakarida yang terkandung dalam ikan adalah glikogen. Glikogen adalah polisakarida dalam tubuh hewan yang tidak larut dalam air dengan iodium memberi warna merah.

Protein terbentuk dari unsur-unsur 
organik yang relatif sama dengan karbohidrat dan lemak, yaitu sama-sama terdiri dari unsur-unsur karbon, hidrogen, dan oksigen, tetapi bagi protein unsur-unsur ini ditambah lagi dengan unsur nitrogen, dan ditemukan pula mineral. Molekul protein tersusun dari asam amino, 12 sampai 18 macam asam amino yang saling berhubungan. Protein
Lemak dalam makanan mempunyai peranan yang penting sebagai sumber tenaga. Bahkan dibandingkan dengan protein dan karbihidrat, lemak dapat menghasilkan tenaga yang lebih besar, yaitu dari 1 gr lemak diperoleh $9 \mathrm{kkal}$.

Meningkatnya kadar lemak dengan suhu pengeringan yang tinggi dapat

Tabel 3. Uji Organoleptik Mutu Hedonik dalam Tepung Daging Ikan Tuna (Thunnus sp)

\begin{tabular}{|c|c|c|c|c|c|c|c|c|}
\hline & \multicolumn{8}{|c|}{ Mutu Hedonik } \\
\hline & \multicolumn{2}{|c|}{ Warna } & \multicolumn{2}{|c|}{ Aroma } & \multicolumn{2}{|c|}{ Tekstur } & \multicolumn{2}{|c|}{ overall } \\
\hline & $\mathrm{K}$ & $\mathrm{S}$ & $\mathrm{K}$ & $\mathrm{S}$ & $\mathrm{K}$ & $\mathrm{S}$ & $\mathrm{K}$ & $\mathrm{S}$ \\
\hline FI $\left(40^{\circ} \mathrm{C}\right)$ & Gelap & 2,9 & $\begin{array}{c}\text { Agak Tidak } \\
\text { Harum }\end{array}$ & 3,1 & $\begin{array}{c}\text { Agak Tidak } \\
\text { Halus }\end{array}$ & 3,5 & $\begin{array}{c}\text { Agak Tidak } \\
\text { Baik }\end{array}$ & 3,7 \\
\hline $\mathrm{F} 2\left(50^{\circ} \mathrm{C}\right)$ & Biasa/Netral & 4,5 & Biasa & 4,4 & Agak Halus & 5,2 & Agak Baik & 5,3 \\
\hline $\mathrm{F} 3\left(60^{\circ} \mathrm{C}\right)$ & Biasa/Netral & 4,3 & Biasa & 4,7 & Agak Halus & 5,8 & Agak Baik & 5,4 \\
\hline
\end{tabular}

Sumber: Data Primer, 2017

dibutuhkan tubuh untuk melakukan fungsinya sebagai zat pembangun bagi pertumbuhan dan pemeliharaan jaringan tubuh, pengantur kelangsungan proses di dalam tubuh dan sebagai pemberi.

Kenaikan nilai kadar protein ini terus berlangsung dengan semakin tingginya suhu yang digunakan selama proses pegeringan tepung. Hal ini dikarenakan semakin tingginya suhu pengeringan akan semakin menyebabkan peningkatan kadar protein pada tepung daging ikan tuna, tinggi atau rendahnya nilai protein yang terukur dapat dipengaruhi oleh besarnya kandungan air yang hilang (dehidrasi) dari bahan . disebabkan oleh penurunan kadar air sehingga persentase kadar lemak meningkat (Zuhra et al., 2012). Kadar lemak yang naik turun disebabkan karena asam lemak tak jenuh yang mengalami pemecahan ikatan rangkap pada lemak, sehingga lemak tersebut akan terdekomposisi menjadi gliserol dan asam lemak. Dari hasil di atas dapat diketahui perbedaan suhu pengeringan akan memberikan kadar lemak yang berbeda. Tingkat kerusakannya sangat bervariasi tergantung suhu yang digunakan selama proses pengolahan (Syahruddin, 2015).

Berdasarkan hasil analisis kadar zat besi dari beberapa sampel tepung daging 
ikan tuna, diketahui kadar yang tertinggi pada suhu $40^{\circ} \mathrm{C}$ kadar zat besi yaitu 1,49 $\mathrm{ug} / \mathrm{g}$. selanjutnya tepung daging ikan tuna pada suhu $60^{\circ} \mathrm{C}$ kadar zat besi sebanyak $1,47 \mathrm{ug} / \mathrm{g}$ dan terendah tepung daging ikan tuna pada suhu $50^{\circ} \mathrm{C}$ kadar zat besi 1,38 ug/g. Kadar zat besi dari ketiga metode nyebabkan bervariasinya nilai pada perbandingan yang lain dikarenakan masih adanya kandungan air dalam tepung daging ikan tuna dan pada saat dititrasi dua kali dilakukan penyaringan untuk mendapatkan hasil yang baik. Karena air merupakan komponen penting dalam bahan makanan

Tabel 4. Uji Hedonik dalam Tepung Daging Ikan Tuna (Thunnus sp)

\begin{tabular}{|c|c|c|c|c|c|c|c|c|c|}
\hline \multirow{3}{*}{ Hedonik } & \multicolumn{9}{|c|}{ Formula } \\
\hline & \multicolumn{3}{|c|}{$\mathrm{F} 1\left(40^{\circ} \mathrm{C}\right)$} & \multicolumn{3}{|c|}{$\mathrm{F} 2\left(50^{\circ} \mathrm{C}\right)$} & \multicolumn{3}{|c|}{$\mathrm{F} 3\left(60^{\circ}\right)$} \\
\hline & $\mathrm{P}$ & $\mathrm{S}$ & $\%$ & $\mathrm{P}$ & $\mathrm{S}$ & $\%$ & $\mathrm{P}$ & $\mathrm{S}$ & $\%$ \\
\hline Sangat-sangat tidak suka sekali & 2 & 2 & 0 & 0 & 0 & 0 & 0 & 0 & 0 \\
\hline Sangat-sangat tidak suka & 0 & 0 & 0 & 0 & 0 & 0 & 0 & 0 & 0 \\
\hline Sangat tidak suka & 4 & 12 & 8 & 3 & 9 & 2 & 0 & 0 & 0 \\
\hline Tidak suka & 11 & 44 & 10 & 0 & 0 & 0 & 2 & 8 & 2 \\
\hline Agak tidak suka & 7 & 35 & 8 & 8 & 40 & 9 & 3 & 15 & 3 \\
\hline Biasa & 3 & 18 & 4 & 5 & 30 & 7 & 4 & 24 & 5 \\
\hline Agak suka & 6 & 42 & 10 & 7 & 49 & 11 & 10 & 70 & 16 \\
\hline Suka & 5 & 40 & 9 & 12 & 96 & 22 & 8 & 64 & 15 \\
\hline Sangat suka & 1 & 9 & 2 & 1 & 9 & 2 & 9 & 81 & 18 \\
\hline Sangat-sangat suka & 0 & 0 & 0 & 2 & 20 & 4 & 2 & 20 & 4 \\
\hline Sangat sangat suka sekali & 1 & 11 & 3 & 2 & 22 & 5 & 2 & 22 & 5 \\
\hline Total & 40 & 213 & 54 & 40 & 275 & 62 & 40 & 304 & 68 \\
\hline
\end{tabular}

Sumber: Data Primer, 2017

pengeringan tidak menunjukkan adanya perbedaan yang cukup tinggi karena disebebkan oleh konsentrasi airnya yang terkandung. Sedangkan hasil penelitian Putri, (2012) nilai zat besi (Fe) dalam 100 gram daging ikan segar sebanyak 2,7 ug/g.

Menurut (Arvianto et al., 2016)faktor yang menyebabkan perbedaan kandungan zat besi pada tepung daging ikan tuna ialah proses pemanasan. Semakin lama proses pemanasan akan menyebabkan solubility zat besi semakin rendah. Namun yang me- yang dapat mempengaruhi penampakan, tekstur serta cita rasa makanan tersebut.

Total mikroba dari tepung dari daging ikan tuna pengeringan dengan suhu $40^{\circ} \mathrm{C}$ sebesar 14.986,6 koloni/gram, tepung daging ikan tuna pada suhu $50^{\circ} \mathrm{C}$ sebesar $12.750 \mathrm{koloni} /$ gram, sedangkan total mikroba tepung daging ikan tuna pada suhu $60^{\circ} \mathrm{C} 2.176,6$ koloni/gram. Total cemaran mikroba tersebut tidak melebihi batas maksimal Standar Nasional Indonesia No. 7388:2009 tentang tepung terigu, untuk 
nilai total koloni mikroba maksimal 1.000.000 koloni/gram.

Berdasarkan SNI tepung, maka untuk tepung daging ikan tuna berada pada kategori aman. Hal ini sesuai dengan penelitian yang dilakukan oleh Haryanti \& Hidajati (2013), tingginya nilai total mikroba pada tepung cacing sutra (Tubifex sp.) pengeringan dalam oven memiliki nilai total bakteri lebih rendah karena mikroba yang ada dalam sampel mati akibat tingginya suhu pengeringan.

Berdasarkan hasil uji laboratorium Analisis jumlah total mikroba kapang dari tepung daging ikan tuna terdapat pada suhu $60^{\circ} \mathrm{C}$ dengan total kapang sebanyak $4.666,6$ koloni/gram,dikategorikan aman, pada suhu $50^{\circ} \mathrm{C}$ dengan total kapang sebanyak 35.813,3 koloni/gram, dikategorikan tidak aman, dan pada suhu $60^{\circ} \mathrm{C}$ dengan total kapang sebanyak 42.623,3 koloni/gram, dikategorikan tidak aman karena melebihi amban batas. Total cemaran kapang untuk pengeringan pada suhu $50^{\circ} \mathrm{C}$ dan pada suhu $60^{\circ} \mathrm{C}$ tersebut telah melebihi batas maksimal Standar Nasional Indonesia No. 7388:2009 tentang tepung terigu, untuk nilai total cemaran mikroba kapang maksimal 10.000 koloni/gram. Berdasarkan SNI tersebut, tepung daging ikan tuna dengan dua metode pengeringan berada pada kategori tidak aman. Jenis pathogen yang terdapat pada ikan tuna seperti
Eschericia coli, Salmonella, Vibrio cholera, Enterobecteriacea dan patogen lainnya, E. coli dapat bertahan pada suhu 50 C pada waktu 60 menit (Putri, 2012).

Tingginya angka cemaran kapang pada tepung daging ikan tuna suhu pengeringan $40^{\circ} \mathrm{C}$, diduga disebabkan karena suhu pengeringan yang terlalu rendah. Air dalam bahan pangan juga turut berperan serta dalam tingginya angka kapang dalam tepung daging ikan tuna pada suhu pengeringan $40^{\circ} \mathrm{C}$. Pengeringan dengan waktu yang cukup singkat yaitu sekitar 8 jam dan dengan suhu rendah, memungkinkan kapang masih dapat tumbuh dan berkembang.

Uji hedonik dan uji mutu hedonik terhadap tepung daging ikan tuna paling disuka dan mempunyai kualitas baik adalah dengan suhu $60^{\circ} \mathrm{C}$. Uji Friedman untuk analisa organoleptik menunjukkan ada pengaruh kualitas tepung daging ikan tuna dari aspek warna, aroma, tekstur, mutu overall dan tingkat kesukaan.

Namun untuk formula F1 $\left(40^{\circ} \mathrm{C}\right)$ tidak memenuhi keriteria aroma hal tersebut dipengaruhi rendahnya suhu pada saat pengeringan tepung menjadi lembab. Aroma makanan dalam banyak hal menentukan enak atau tidaknya makanan bahkan aroma atau bau-bauan lebih kompleks dari pada rasa dan kepekaan indera pembauan biasanya lebih tinggi dari indera pencicipan bahkan industri pangan menganggap sangat 
penting terhadap uji bau karena dapat dengan cepat memberikan hasil penilaian apakah produk disukai atau tidak (Winarno, 2002)

\section{KESIMPULAN}

Berdasarkan hasil penelitian yang dilakukan oleh peneliti, maka dapat di tarik beberapa kesimpulan: (1) Semakin tinggi suhu pengeringan maka semakin sedikit kandungan kadar air pada tepung daging ikan tuna. (2) Semakin tinggi suhu pengeringan maka semakin tinggi kandungan kadar abu pada tepung daging ikan tuna. (3) Semakin tinggi suhu pengeringan maka semakin tinggi kandungan karbohidrat pada tepung daging ikan tuna. (4) Semakin tinggi suhu pengeringan maka semakin tinggi kandungan protein pada tepung daging ikan tuna. (5) Suhu penegeringan pada kadar lemak pada tepung daging ikan tuna tidak mengalami kenaikan yang singnifikan. (6) Semakin rendah suhu pengeringan maka semakin tinggi kandungan zat besi (Fe) pada tepung daging ikan tuna. (7) Cemaran mikroba bakteri untuk tepung daging ikan tuna dengan tiga metode pengeringan, untuk jumlah koloni bakteri semua berada dikategori aman, sementara untuk cemaran mikroba kapang untuk tepung daging ikan tuna, yang dikategorikan aman berada pada suhu $60^{\circ} \mathrm{C}$ sebanyak 4,666,6 koloni/gram. (8) Uji he- donik dan uji mutu hedonik terhadap tepung daging ikan tuna paling disuka dan mempunyai kualitas baik adalah dengan suhu $60^{\circ} \mathrm{C}$. Uji Friedman untuk analisa organoleptik menunjukkan ada pengaruh kualitas tepung daging ikan tuna dari aspek warna, aroma, tekstur, mutu overall dan tingkat kesukaan.

\section{SARAN}

Berdasarkan hasil penelitian, maka saran yang dapat dikemukakan adalah sebagai berikut: (1) Bagi pemerintah, pentingnya untuk melakukan beberapa diversifikasi pangan untuk meningkatkan daya tarik masyarakat mengkonsumsi makanan yang bergizi untuk memperbaiki status gizi masyarakat. (2) Bagi masyarakat dapat membuat tepung daging ikan tuna untuk menjadi makanan layak konsumsi sebagai makanan tambahan guna memenuhi kebutuhan zat gizi perharinya. (3) Diperlukan penelitian lebih lanjut tentang zat gizi lain yang terkandung dalam tepung daging ikan tuna serta senantiasa lebih mengacu pada prospek Islam guna mengembangkan pendapat masyarakat ditinjau dari segi Islam.

\section{DAFTAR PUSTAKA}

Arvianto, A. A., Swastawati, F., \& Wijayanti, I. (2016). Pengaruh fortifikasi tepung daging ikan lele dumbo (Clarias gariepinus) terhadap kandungan asam ami- 
no lisin pada biskuit. Jurnal Pengolahan Dan Bioteknologi Hasil Perikanan, 5(4), 20-25.

Belton, B., \& Thilsted, S. H. (2014). Fisheries in transition: Food and nutrition security implications for the global South. Global Food Security, 3(1), 59-66. https://doi.org/10.1016/j.gfs.2013.10.001

Fatmawati, \& Mardiana. (2014). Tepung Ikan Gabus Sebagai Sumber Protein (Food Supplement). Jurnal Bionature, 15(1), 54-60.

Hadinoto, S., \& Idrus, S. (2018). Proporsi dan Kadar Proksimat Bagian Tubuh Ikan Tuna Ekor Kuning (Thunnus albacares) Dari Perairan Maluku. Majalah BIAM, 14(2), 51 . https://doi.org/10.29360/mb.v14i2.4212

Haryanti, D. N., \& Hidajati, N. (2013). Effect of drying method of wheat quality silk worms ( Tubifex sp . ). UNESA Jurnal Of Chemestry, 2(3), 71-76.

Putri, R. H. K. (2012). Uji organoleptik formulasi Cookies kaya gizi sebagai makanan tambahan dalam upaya penanggulangan anemia ibu hamil kepada ibu hamil dengan berbagai usia kehamilan di Rangkapan Jaya Depok 2011. Universitas Indonesia.

Rahmantya, Asianto, K. F., Destiti, A., \& Wibowo, D. (2015). Analisis Data Pokok Kementerian Kelautan dan Perikanan.

Sudarmadji, S. (2007). Prosedur analisa untuk bahan makanan \& pertanian. Liberty.

Syahruddin, A. N. (2015). Identifikasi zat gizi dan kualitas tepung kulit pisang raja (Musa sapientum) dengan metode pengeringan sinar matahari dan oven. Media Gizi Pangan, 1(2), 116-121.

Winarno, F. G. (2002). Kimia Pangan dan gizi. P.T. Gramedia Pustaka Utama. https://books.google.co.id/books?id=_P4St AEACAAJ

Zuhra, Sofyanan, \& Erlina, C. (2012). Pengaruh Kondisi Operasi Alat Pengering Semprot Terhadap Kualitas Susu Bubuk Jagung. Jurnal Rekayasa Kimia \& Lingkungan, 9(1), 36-44. 